\title{
Pemodelan Distribusi Nitrat di Kawasan Perairan Teluk Benoa
}

\author{
I Made Dharma Raharja ${ }^{a}$, I Gede Hendrawan ${ }^{a}$, Yulianto Suteja ${ }^{a}$ \\ ${ }^{a}$ Program Studi Ilmu Kelautan, Fakultas Kelautan dan Perikanan, Universitas Udayana, Kampus UNUD Bukit Jimbaran, Bali 80361, Indonesia
}

\section{ARTICLE INFO}

ABSTRACT

Article history:

Received $19^{\text {th }}$ July 2018

Received in revised form $20^{\text {th }}$ August 2018

Accepted $1^{\text {th }}$ October 2018

Available online $8^{\text {th }}$ November 2018

Keywords:

Nitrate

Benoa Bay

FVCOM

Advection

Diffusion

\begin{abstract}
Benoa Bay is a highly affected waters by its environmental conditions such as nitrate. From previous research on nitrate consent and contamination load in Benoa Bay, the nitrate condition has exceeded the quality standard of the Bali Governor Regulation No. 16 of 2016 of 0,008 $\mathrm{mg} / \mathrm{L}$ but the previous research is only on the surface and it's important to conduct further research related to the nitrate conditions in water coloumn of Benoa Bay. In this study using numerical modeling. The numerical modeler in this study is Finite Volume Coastal Ocean Model (FVCOM) which is modeled in 3-D. There's two steps in running the model, first do the numerical modeling of hydrodynamics and the second do the advection-diffusion numerical modeling. From the model results for each tide condition the nitrate concentration at the surface of the Benoa Bay is high in the west and the east side of Benoa Bay. The tidal elevation conditions tend to affect the concentration of nitrate in the water column at the centre area of Benoa Bay and nitrate concentration from the surface to the bottom of the water have similar consentration, besides that the nitrate concentration will be high towards the land but will be decrease toward the sea.
\end{abstract}

2018 JMRT. All rights reserved.

\section{Pendahuluan}

Kualitas perairan merupakan salah satu parameter penting untuk menentukan tingkat kesehatan suatu lingkungan bagi ekosistem di pesisir, serta nitrat merupakan salah satu unsur hara yang dominan berada di suatu perairan (Simanjuntak, 2012; Hendrawan et al., 2016). Pengkayaan nitrat di lingkungan perairan bisa memberikan dampak positif untuk produksi fitoplankton dan negatif ketika kondisi nitrat berlebih sehingga terjadi Harmful Algal Blooms (HABs) (Risamasu and Prayitno, 2012).

Secara umum nitrat bersumber dari aktivitas limbah industri dan aktivitas pemukiman (Suteja, 2016; Rahayu et al., 2018). Selain aktivitas tersebut keberadaan nitrat juga berasal dari perairan itu sendiri karena adanya penguraian, pelapukan ataupun dekomposisi dari aktivitas biologis di perairan (Patty et al., 2015). Banyak kasus telah ditemukan di Indonesia terkait kondisi nitrat berlebih, sehingga turunnya kualiatas perairan pada daerah terebut dan terjadinya eutrofikasi. Tempat tersebut diantaranya Teluk Ambon, Teluk Jakarta, dan Perairan Pantai Ancol (Tuahattu and Tubalanowy, 2008; LIPI, 2015; LIPI, 2017).

Teluk Benoa merupakan daerah estuari yang berada di Provinsi Bali yang memiliki aktivitas yang padat untuk kegiatan rekreasi, wisata air dan lalu lintas kapal (KLHK, 2015; Maharta, 2018). Terdapat beberapa sungai yang bermuara di Teluk Benoa, yaitu: sungai Bualu, sungai Sama, sungai Mati, sungai Badung, sungai Buaji dan sungai Loloan (Risuana et al., 2017). Dari penelitian sebelumnya terkait beban pencemaran nitrat dan konsentrasi nitrat secara spasial di Perairan Teluk Benoa telah melewati Baku Mutu Lingkungan Hidup dan Baku Mutu Kerusakan Lingkungan Hidup sesuai Peraturan Gubernur Bali
Nomor 16 Tahun 2016, yaitu 0,008 mg/L (KLHK, 2015; Rahayu et al., 2018).

Dalam mengkaji kondisi di suatu perairan terdapat beberapa metode yang bisa digunakan, salah satunya metode pemodelan numerik. Pemodelan numerik merupakan metode yang mampu memodelkan suatu keadaan dari keadaan sebelumnya maupun dimasa datang misalnya seperti pergerakan limbah atau polutan, sedimen, partikel dan lainnya (Chen et al., 2006; Maharta et al., 2019). Peneltian menggunakan pemodelan numerik sebelumnya pernah dilakukan di Teluk Benoa yaitu pada penelitian Hendrawan and Ardana (2010) menggunakann Priceton Ocean Model (POM) untuk mengetahui konsentrasi fosfat di permukaan perairan Teluk Benoa, Hendrawan and Asai (2014) menggunakan Finite Volume Coastal Ocean Model (FVCOM) untuk mengkaji arus pasang surut dan pertukaran massa air di Teluk Benoa. Rachman et al. (2016) menggunakan Finite Volume Coastal Ocean Model (FVCOM) untuk mengkaji pergerakan sedimen permukaan dan kolom perairan di Teluk Benoa, dan Maharta (2018) menggunakan Finite Volume Coastal Ocean Model (FVCOM) untuk mengkaji laju sedimentasi pada Teluk Benoa. Namun penelitian pemodelan numerik menggunakan FVCOM terkait konsentrasi nitrat di Teluk Benoa belum pernah dilakukan.

Pemodelan numerik yang digunakan dalam penelitian ini adalah Finite Volume Coastal Ocean Model (FVCOM). Pada penelitian ini menggunakan model FVCOM 3-D. Model FVCOM tepat diterapkan di perairan Teluk Benoa karena Teluk Benoa memiliki wilayah coastline (garis pantai) yang rumit dan FVCOM memiliki metode finite-element untuk mengatasi wilayah coastline yang rumit seperti Teluk Benoa. 
Dengan adanya permasalahan konsentrasi nitrat yang tinggi di Teluk Benoa pada penelitian sebelumnya yang dilakukan oleh KLHK (2015) dan Rahayu et al. (2018) dan analisis nitrat pada penelitian sebelumnya masih terbatas pada bagian permukaan perairan Teluk Benoa, sehingga penting halnya melakukan penelitian konsentrasi nitrat lebih lanjut di Teluk Benoa menggunakan FVCOM 3-D yang akan dimodelkan secara spasial.

\section{Metode}

\subsection{Lokasi Penelitian}

Pengambilan data untuk input model diambil pada 29 Januari 2018 dan data untuk validasi model diambil pada 14 Februari 2018. Sementara untuk data debit sungai diambil setiap dua kali dalam seminggu dari 29 Januari - 14 Februari 2018. Pengambilan data dilaksanakan pada waktu tersebut untuk mewakili kondisi saat musim hujan. Lokasi pengambilan data input model dan initial condition dapat dilihat pada Gambar 1 dan Gambar 2.
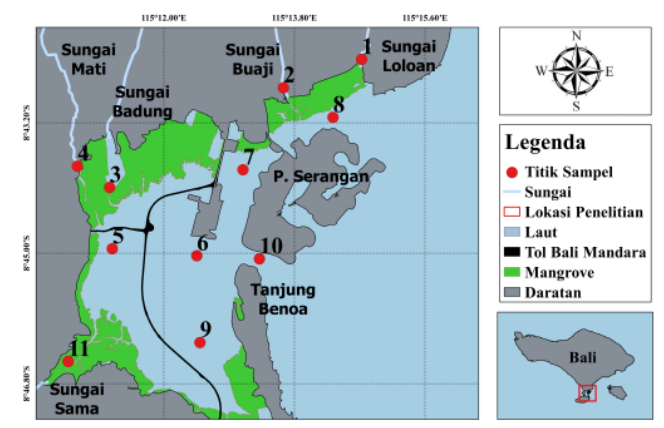

Gambar 1. Peta Lokasi Input Data Model
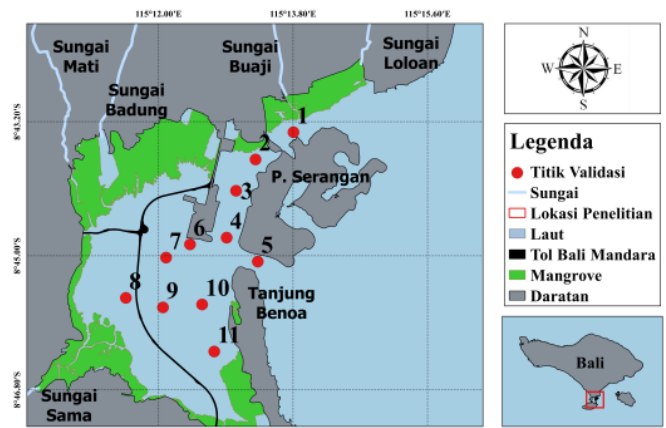

Gambar 2. Peta Lokasi Validasi Model Nitrat

\subsection{Desain Model}

Model dijalankan selama 31 hari. Layer dalam model berjumlah 10 layer. Komponen elevasi pasang surut yang digunakan untuk model berjumlah 4 komponen yaitu S2, M2, $\mathrm{K} 1$, dan $\mathrm{O} 1$ yang besumber dari Ocean Research Institute (ORI), Universitas Tokyo (ORI-Tide) (Matsumoto et al., 1995). Data batimetri bersumber dari pengeruman pada tahun 2012 oleh PT. Tirta Wahana Bali International (PT. TWBI) (bagian dalam teluk) dan Dishidros TNI AL edisi tahun 2006 (bagian luar teluk) dengan koreksi Low Water Level. Input sungai dalam domain model berjumlah 5 sungai (sungai Loloan, sungai Buaji, sungai Badung, sungai Mati, dan sungai Sama). Grid yang digunakan dalam model adalah unstructural triangular grid dengan resolusi 200 meter untuk bagian coastline, serta 500 meter untuk daerah open boundary (batas terbuka). Domain model lebih jelasnya dilihat pada Gambar 3.

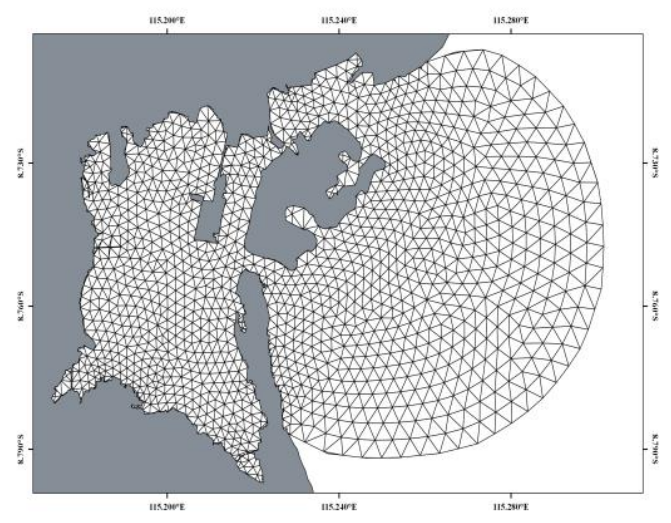

Gambar 3. Domain Model

\subsection{Model Hidrodinamika}

Persamaan hidrostatis tiga dimensi (3D) yang terdapat dalam FVCOM terdiri dari persamaan kontinuitas dan momentum (1-3), suhu (4), salinitas (5), densitas (6), dan elevasi pasang surut (7) (Chen et al., 2006):

$$
\begin{aligned}
& \frac{\partial \zeta}{\partial t}+\frac{\partial D u}{\partial x}+\frac{\partial D v}{\partial y}+\frac{\partial \omega}{\partial \sigma}=0 \\
& \frac{\partial u D}{\partial t}+\frac{\partial u^{2} D}{\partial x}+\frac{\partial u v D}{\partial y}+\frac{\partial u \omega}{\partial \sigma}-f v D=-g D \frac{\partial \zeta}{\partial x}- \\
& \frac{g D}{\rho_{0}}\left[\frac{\partial}{\partial x}\left(D \int_{\sigma}^{0} \rho d \sigma^{\prime}\right)+\partial \rho \frac{\partial D}{\partial x}\right]+\frac{1}{D} \frac{\partial}{\partial \sigma}\left(K_{m} \frac{\partial u}{\partial \sigma}\right) \\
& +D F \\
& x \\
& \frac{\partial v D}{\partial t}+\frac{\partial v^{2} D}{\partial x}+\frac{\partial u v D}{\partial y}+\frac{\partial v \omega}{\partial \sigma}-f u D=-g D \frac{\partial \zeta}{\partial y}- \\
& \frac{g D}{\rho_{0}}\left[\frac{\partial}{\partial y}\left(D \int_{\sigma}^{0} \rho d \sigma^{\prime}\right)+\partial \rho \frac{\partial D}{\partial y}\right]+\frac{1}{D} \frac{\partial}{\partial \sigma}\left(K_{m} \frac{\partial v}{\partial \sigma}\right) \\
& +D F \\
& y
\end{aligned}
$$

$$
+D F_{S}
$$

$\rho=\rho(T, S)$

$$
\zeta_{0}=\bar{\zeta}_{0}+\sum_{i=1}^{N_{0}} \zeta_{i} \cos \left(\omega_{i} t-\theta_{i}\right)
$$


dimana $\mathrm{x}$ adalah arah untuk Timur dan Barat, y adalah arah untuk Utara dan Selatan, dan $\sigma$ adalah arah vertikal dalam sistem koordinat kartesian; $\mathrm{u}, \mathrm{v}$, dan $\omega$ adalah komponen kecepatan arus $(\mathrm{m} / \mathrm{s})$ untuk arah $\mathrm{x}, \mathrm{y}, \sigma$; T adalah suhu $\left({ }^{\circ} \mathrm{C}\right)$; $\mathrm{S}$ adalah salinitas (ppt); $\rho$ adalah denistas akhir $(\mathrm{Pa})$ sedangkan $\rho_{0}$ adalah densitas awal (Pa); $\mathrm{f}$ adalah gaya coriolis $\left(^{\circ}\right)$; g adalah gravitasi $(\mathrm{m} / \mathrm{s}) ; \mathrm{K}_{\mathrm{m}}$ adalah vertical eddy viscosity $\left(\mathrm{m}^{2} / \mathrm{s}\right)$; dan $\mathrm{K}_{\mathrm{h}}$ adalah thermal vertical eddy diffusion coefficient $\left(\mathrm{m}^{2} / \mathrm{s}\right) . \mathrm{F}_{\mathrm{X}}, \mathrm{F}_{\mathrm{Y}}, \mathrm{F}_{\mathrm{T}}$, dan $\mathrm{F}_{\mathrm{S}}$ mempresentasikan dari gesekan arah $\mathrm{x}$ dan $\mathrm{y}$, thermal, dan difusi salinitas (N); D adalah total kedalaman kolom perairan (m); H adalah penyerapan radiasi ke kolom perairan; $\zeta$ adalah tinggi elevasi permukaan perairan $(\mathrm{m}) ; \zeta_{i}, \omega_{i}, \theta_{i}$ mempresentasikan amplitudo (m), frekuensi (s), dan phase dari pasang surut $\left(^{\circ}\right) ; \mathrm{t}$ adalah waktu (s).

\subsection{Model Adveksi-Difusi}

Model Adveksi - Difusi merupakan suatu model yang digunakan untuk menyelesaikan proses adveksi dan difusi dari suatu konsentrasi polutan atau limbah. Persamaan yang digunakan dalam Model Adveksi - Difusi adalah sebagai berikut seperti yang dituliskan pada persamaan (8) (Chen et al., 2006):

$$
\begin{aligned}
& \frac{\partial D C}{\partial t}+\frac{\partial D u C}{\partial x}+\frac{\partial D \nu C}{\partial y}+\frac{\partial \omega C}{\partial \sigma}-\frac{1}{D} \frac{\partial}{\partial \sigma}\left(K_{h} \frac{\partial C}{\partial \sigma}\right) \\
& +F_{c}=D C_{0}(x, y, t, \sigma)
\end{aligned}
$$

dimana $\mathrm{C}$ adalah konsentrasi polutan, $\mathrm{D}$ adalah total kedalaman kolom perairan, u, v, dan $\omega$ adalah komponen kecepatan arus $(\mathrm{m} / \mathrm{s})$ untuk arah $\mathrm{x}, \mathrm{y}$, dan $\sigma ; \mathrm{t}$ adalah waktu; Kh adalah thermal vertical eddy diffusion coefficient $\left(\mathrm{m}^{2} / \mathrm{s}\right) ; \mathrm{Fc}$ adalah horizontal diffusion coefficient $\left(\mathrm{m}^{2} / \mathrm{s}\right)$; dan $\mathrm{C} 0$ adalah konsentrasi polutan yang dilepaskan dari titik sumber $(\mathrm{mg} / \mathrm{l})$.

Koefisien yang digunakan dalam model nitrat bersumber dari beberapa daerah penelitian sebelumnya yang disesuaikan untuk perairan yang memiliki kondisi mixing zone, memiliki suhu $29^{\circ} \mathrm{C}$ dan salinitas $32^{\circ} \mathrm{C}$. Adapun koefisien yang digunakan seperti yang dituliskan pada Tabel 1 .

Tabel 1. Koefisien Model Nitrat

\begin{tabular}{lll}
\hline Koefisien & Nilai & Sumber \\
\hline $\mathrm{F}_{\mathrm{C}}\left(\mathrm{m}^{2} / \mathrm{s}\right)$ & 0.194 & Boudreau, 1997 \\
$\mathrm{K}_{\mathrm{m}}\left(\mathrm{m}^{2} / \mathrm{s}\right)$ & $10^{-5}$ & Galperin et al., 1988 \\
$\mathrm{~K}_{\mathrm{h}}\left(\mathrm{m}^{2} / \mathrm{s}\right)$ & $10^{-5}$ & Galperin et al., 1988 \\
\hline
\end{tabular}

\subsection{Analisis Data}

Dalam melakukan analisis konsentrasi nitrat dilakukan pembagian beberapa daerah untuk analisis data, baik pada permukaan perairan dan kolom perairan sesuai daerah domain model. Daerah analisis dibagi menjadi empat daerah berdasarkan keberadaan aliran sungai dan daerah yang tidak mimiliki sungai namun terpengaruh oleh aliran sungai dari daerah lain, pembagian daerah tersebut sebagai berikut: (I) Daerah Tengah Teluk, Timur Teluk Benoa merupakan daerah yang tidak memiliki aliran sungai namun dipengaruhi aliran sungai yang bersumber dari Barat Teluk Benoa dan Selatan Teluk Benoa; (II) Daerah Selatan Selatan Benoa merupakan daerah yang dipengaruhi oleh aliran Sungai Sama; (III) Daerah Barat Teluk Benoa merupakan Daerah yang dipengaruhi oleh aliran Sungai Badung dan Sungai Mati; (IV) Daerah Timur Teluk Benoa; merupakan daerah yang dipengaruhi oleh aliran Sungai Loloan dan Sungai Buaji. Pembagian daerah penelitian lebih jelasnya dapat dilihat pada Gambar 4

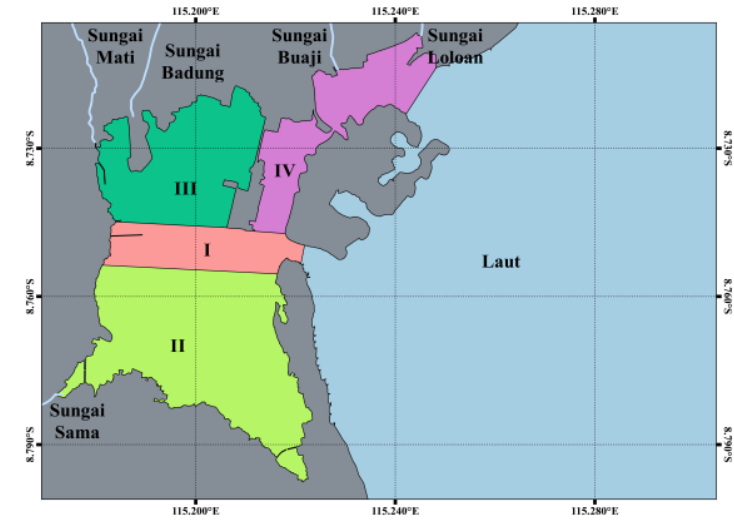

Gambar 4. Pembagian Daerah Analisis

Analisis data konsentrasi nitrat dilakukan pada bagian permukaan dan kolom perairan. Data permukaan yang dimaksud adalah data konsentasi nitrat di layer permukaan pada model sementara data kolom perairan yang dimaksud adalah data konsentrasi nitrat secara vertikal.

Analisis data pada bagian permukaan dilakukan secara spasial sementara analisis data pada kolom perairan dilakukan dengan menggunakan metode cross section secara vertikal dari permukaan hingga dasar perairan pada daerah tengah Teluk Benoa.

\subsection{Validasi Data}

Data yang divalidasi adalah konsentrasi nitrat, arus, dan elevasi pasang surut. Waktu simulasi model untuk memvalidasi data disesuaikan dengan waktu data validasi. Data konsentrasi nitrat dari hasil model divalidasi dengan data pengukuran insitu yang diambil pada tanggal 14 Februari 2018. Data kecepatan arus divalidasi dengan data observasi yang diambil menggunakan Acoustic Doppler Current Profiler (ADCP) tahun 2015 pada 1 periode pasut (21.00 Wita; 5 Juli 2015 - 09.00 Wita; 6 Juli 2015) oleh PT. Tirta Wahana Bali International (PT. TWBI). Sementara data elevasi pasang surut divalidasi menggunakan data pengamatan observasi pada tahun 2016 (17.00 Wita; 17 Desember 2016 - 07.00 Wita; 25 Desember 2016).

Dalam memvalidasi data antara hasil model dengan data validasi atau data observasi dilakukan dengan cara menghitung korelasi (r) untuk mengetahui hubungan antara data hasil model dengan data observsasi. Formula untuk korelasi ditulis pada persamaan (9) (Sugiono, 2012). Sementara perhitungan analisis Root Mean Square Error (RMSE) dilakukan untuk dapat mengetahui nilai error dari hasil model dengan data observasi yang ditulis pada persmaan (9) (Soliwoda, 2014).

$$
\begin{aligned}
& r=\frac{\sum x y-\frac{\left(\sum x\right)\left(\sum y\right)}{n}}{\sqrt{\left(\sum x^{2}-\frac{\left(\sum x\right)^{2}}{n}\right)\left(\sum y^{2}-\frac{\left(\sum y\right)^{2}}{n}\right)}} \\
& R M S E=\sqrt{\frac{E_{i=1}^{i}(x-y)^{2}}{n}}
\end{aligned}
$$

Dimana r adalah koefisien korelasi; RMSE adalah niliai error $\mathrm{x}$ adalah data model; $\mathrm{y}$ adalah data observasi; $\sum \mathrm{xy}$ adalah jumlah antara data model dan data observasi; $\sum x$ jumlah data model; $\sum y$ jumlah data observasi; $n$ adalah jumlah data. 


\section{Hasil dan Pembahasan}

\subsection{Validasi Data}

\section{a. Validasi Arus}

Validasi arus dilakukan dengan membandingkan data model dan data observasi. Lokasi validasi arus antara data model dan data observasi terletak di mulut teluk. Validasi arus dilakukan pada satu periode pasut dari pukul 21.00 Wita pada tanggal $5 \mathrm{Juli}$ 2015 - 09.00 Wita pada tanggal 6 Juli 2015.

Hasil validasi arus antara data model dan observasi untuk komponen u dan komponen v dapat dilihat pada Gambar 5. Hasil perhitungan korelasi antara komponen $\mathrm{u}$ dan komponen $\mathrm{v}$ menunjukan nilai korelasi yang besar dengan nilai korelasi masing-masing adalah 0,88 dan 0,88. Sementara dari hasil perhitungan Root Mean Square Error (RMSE) antara data model dan observasi untuk komponen u dan dan komponen $\mathrm{v}$ diperoleh hasil masing-masing adalah $0,25 \mathrm{~m} / \mathrm{s}$ dan $0,11 \mathrm{~m} / \mathrm{s}$.
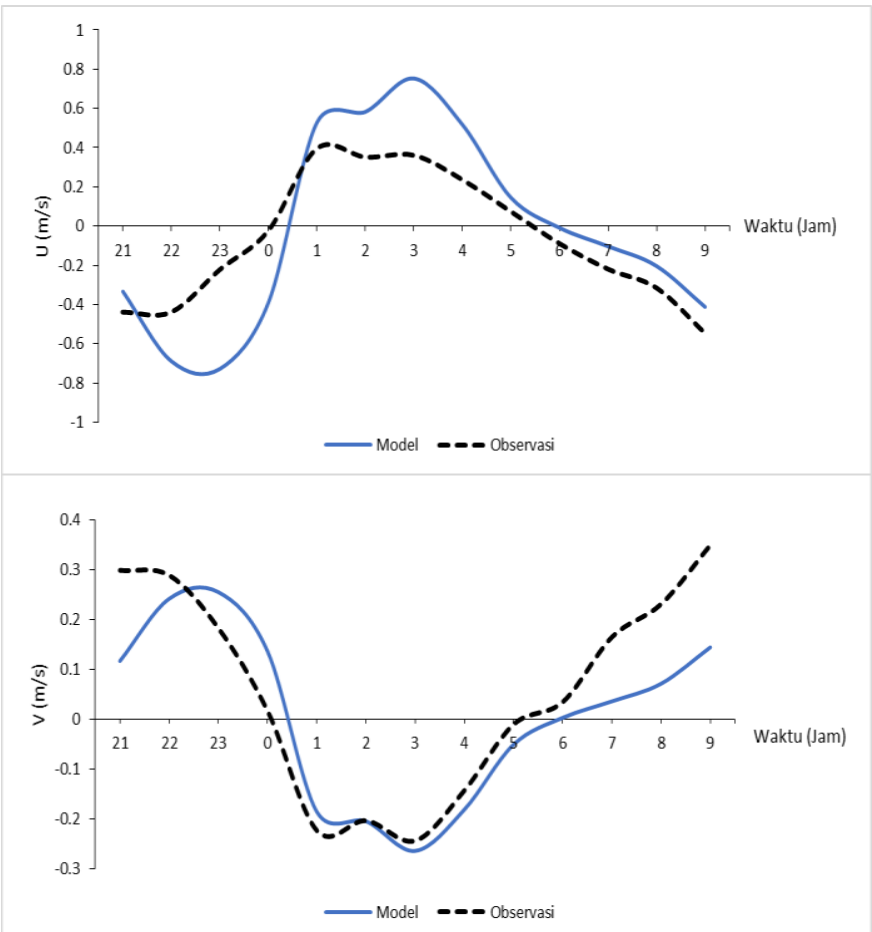

Gambar 5. Validasi Komponen U dan Komponen V

Validasi pola pergerakan dan kecepatan arus antara data model dengan data observasi dapat dilihat pada Gambar 6 dan Gambar 7. Pola arus antara model dan dan data observasi memiliki pola yang sama pada satu peridoe pasut. Kecepatan arus antara data model dengan data observasi memiliki nilai korelasi sebesar 0,5 sedangkan dari perhitungan RMSE memiliki nilai $0,25 \mathrm{~m} / \mathrm{s}$.

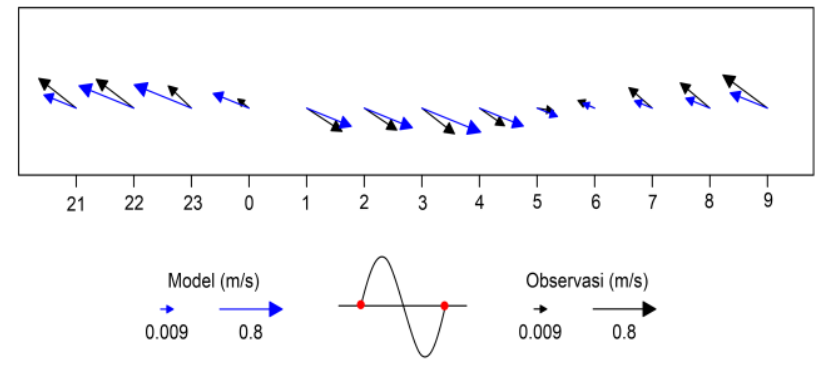

Gambar 6. Validasi Pola Pergerakan Arus

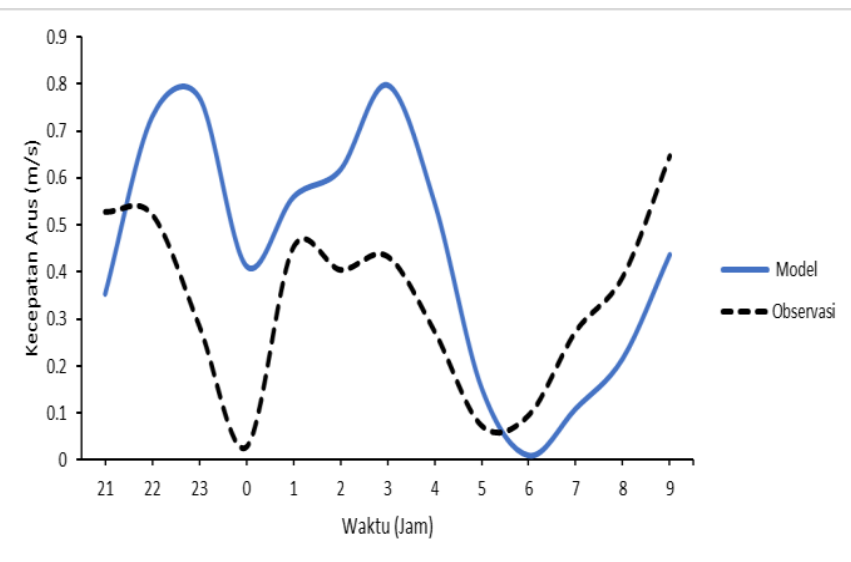

Gambar 7. Validasi Kecepatam Arus

Besarnya error pada komponen u dan kecepatan arus karena pada model yang berlokasi di mulut Teluk Benoa karena pada model tidak mempertimbangkan adanya akvitas seperti gelombang pecah dan aktivitas lalulintas kapal serta pada model hanya menggunakan empat komponen pasut, hal tersebut sesuai menurut Al Tanto (2017) yang menyatakan kondisi arus di mulut teluk dipengaruhi oleh gelombang pecah, pasang surut air laut dan akvitas lalulintas kapal.

\section{b. Validasi Elevasi Pasang Surut}

Dalam validasi elevasi pasang surut dilakukan validasi antara data model dan data observasi dengan data observasi didapat dari pengamatan pasang surut (17.00 Wita; 17 Desember 2016 07.00 Wita; 25 Desember 2016). Validasi elevasi pasang surut dapat dilihat pada Gambar 8. Dari hasil perhitungan korelasi antara data model dan data observasi diperoleh hasil 0,9 sementara dari hasil perhitungan RMSE diperoleh hasil sebesar $0,2 \mathrm{~m}$. Secara umum keadaan elevasi pasang surut model dapat mempresentasikan keadaan elevasi pasang surut di Teluk Benoa.

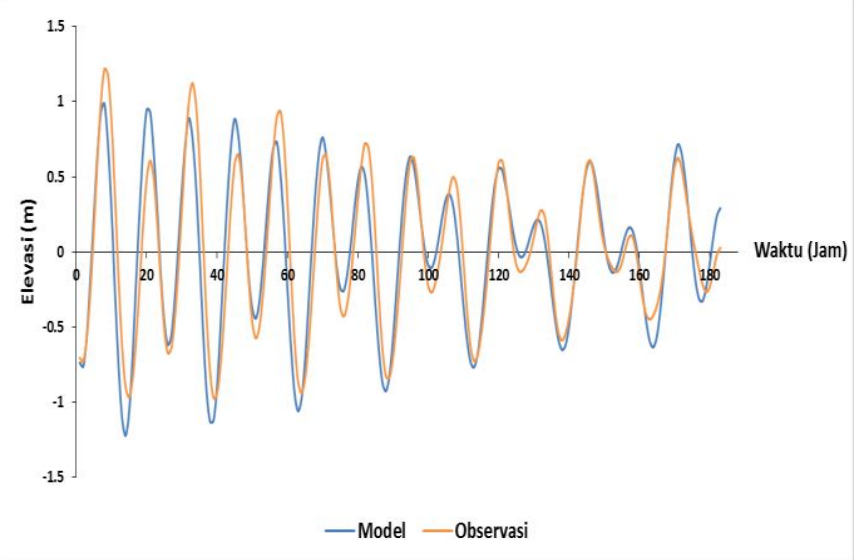

Gambar 8. Validasi Elevasi Pasang Surut

\section{c. Validasi Nitrat}

Validasi nitrat antara data model dan data observasi dapat dilihat pada Gambar 9. Dari hasil perhitungan korelasi antara data model dan data observasi diperoleh nilai sebesar 0,84 sementara dalam perhitungan nilai RMSE diperoleh nilai sebesar $0,08 \mathrm{mg} / \mathrm{L}$. Secara umum antara data model dan data observasi memiliki pola yang relatif sama dan dapat mempresentasikan keadaan nitrat di Perairan Teluk Benoa. 


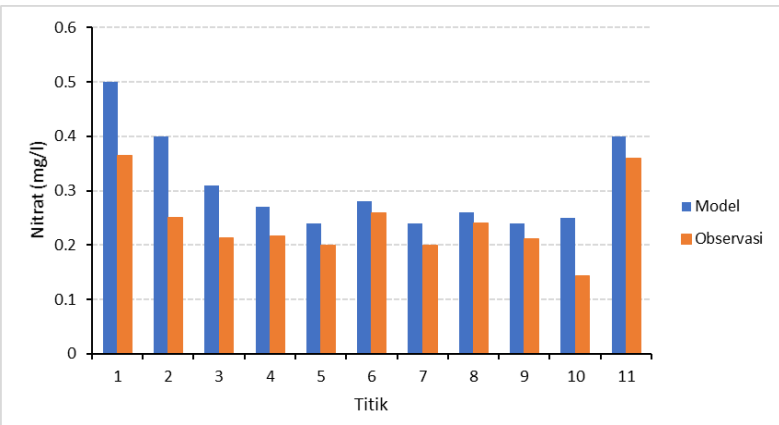

Gambar 9. Validasi Nitrat

\subsection{Pola Distribusi Nitrat di Perairan Teluk Benoa}

\section{a. Pola Distribusi Nitrat di Permukaan Perairan}

Hasil model menunjukkan konsentrasi nitrat di Perairan Teluk Benoa cenderung fluktuatif karena adanya proses adveksi yang disebabkan oleh pergerakan arus pasang surut dan adanya proses difusi. Pola nitrat secara spasial dapat dilihat pada Gambar 10.

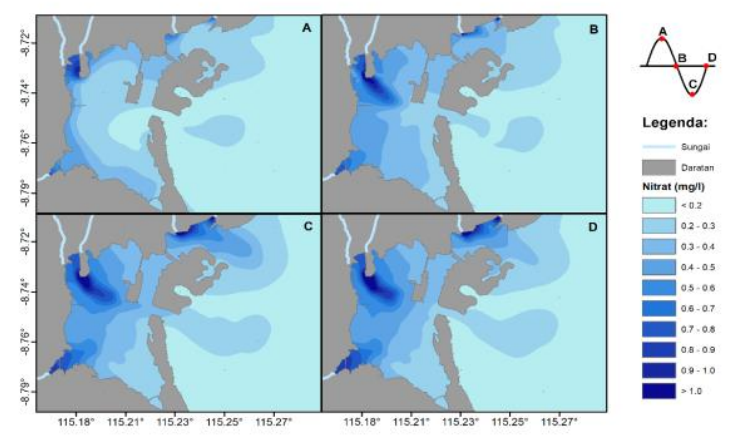

Gambar 10. Pola Distribusi Nitrat Pada Setiap Kondisi Elevasi Pasang Surut

Konsentrasi nitrat pada kondisi pasang tertinggi di Perairan Teluk Benoa dapat dilihat pada Gambar 11. Daerah Barat Teluk Benoa memiliki konsentrasi nitrat rata-rata $0,34 \mathrm{mg} / \mathrm{L}$ dan maksimum 1,02 mg/L. Daerah Timur Teluk Benoa memiliki konsentrasi nitrat rata-rata $0,30 \mathrm{mg} / \mathrm{L}$ dan maksimum $0,78 \mathrm{mg} / \mathrm{L}$. Daerah tengah Teluk Benoa memiliki konsentrasi nitrat rata-rata $0,23 \mathrm{mg} / \mathrm{L}$ dan maksimum $0,43 \mathrm{mg} / \mathrm{L}$. Sementara pada daerah Selatan Teluk Benoa memiliki konsentrasi nitrat rata-rata 0,29 $\mathrm{mg} / \mathrm{L}$ dan maksimum $0,77 \mathrm{mg} / \mathrm{L}$. Pada setiap daerah memiliki konsentrasi nitrat minimum yang sama yakitu $0,2 \mathrm{mg} / \mathrm{L}$.

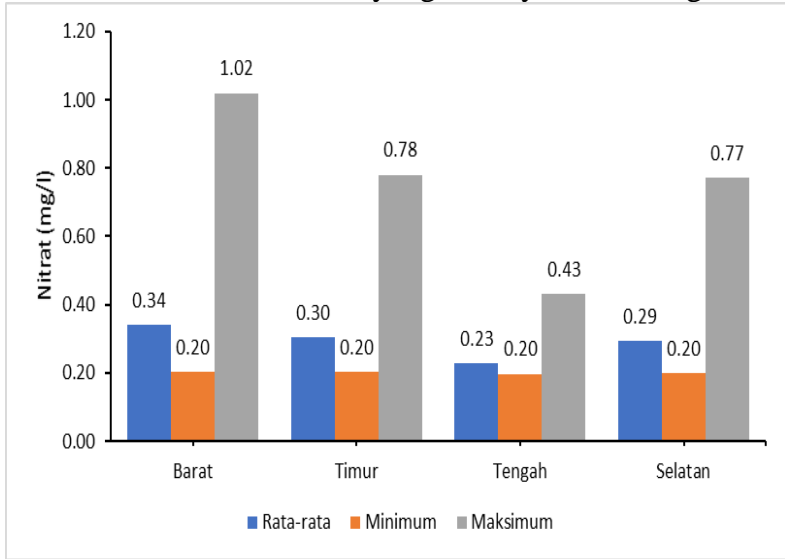

Gambar 11. Grafik Nitrat Kondisi Pasang Tertinggi
Konsentrasi nitrat pada saat kondisi Mean Sea Level (MSL) menuju surut di Perairan Teluk Benoa dapat dilihat pada Gambar 12. Daerah Barat teluk Benoa memiliki konsentrasi nitrat ratarata $0,51 \mathrm{mg} / \mathrm{L}$, minimum $0,29 \mathrm{mg} / \mathrm{L}$, dan maksimum $1,42 \mathrm{mg} / \mathrm{L}$. Daerah Timur Teluk Benoa memiliki konsentrasi nitrat rata-rata $0,37 \mathrm{mg} / \mathrm{L}$, minimum 0,22 mg/L, dan maksimum $1,40 \mathrm{mg} / \mathrm{L}$. Daerah tengah Teluk Benoa memiliki konsentrasi nitrat rata-rata $0,36 \mathrm{mg} / \mathrm{L}$, minimum $0,21 \mathrm{mg} / \mathrm{L}$, dan maksimum $0,68 \mathrm{mg} / \mathrm{L}$. Sementara pada daerah Selatan Teluk Benoa memiliki konsentrasi nitrat rata-rata $0,37 \mathrm{mg} / \mathrm{L}$, minimum $\mathrm{r} 0,1 \mathrm{mg} / \mathrm{L}$ dan maksimum $0,88 \mathrm{mg} / \mathrm{L}$.

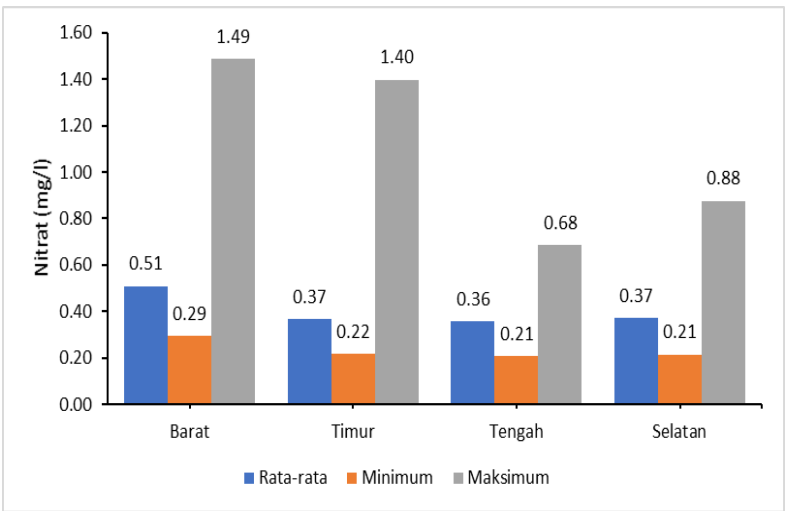

Gambar 12. Grafik Nitrat Kondisi MSL Menuju Surut

Konsentrasi nitrat pada kondisi surut terendah di Periran Teluk Benoa dapat dilihat pada Gambar 13. Daerah Barat teluk Benoa memiliki konsentrasi nitrat rata-rata $0,56 \mathrm{mg} / \mathrm{L}$, minimum 0,36 mg/L, dan maksimum 1,26 mg/L. Daerah Timur Teluk Benoa memiliki konsentrasi nitrat rata-rata $0,46 \mathrm{mg} / \mathrm{L}$, minimum $0,33 \mathrm{mg} / \mathrm{L}$, dan maksimum $1,33 \mathrm{mg} / \mathrm{L}$. Daerah tengah Teluk Benoa memiliki konsentrasi nitrat rata-rata $0,46 \mathrm{mg} / \mathrm{L}$, minimum $0,28 \mathrm{mg} / \mathrm{L}$, dan maksimum $0,77 \mathrm{mg} / \mathrm{L}$. Sementara pada daerah Selatan Teluk Benoa memiliki konsentrasi nitrat rata-rata 0,38 $\mathrm{mg} / \mathrm{L}$, minimum $0,21 \mathrm{mg} / \mathrm{L}$ dan maksimum $0,86 \mathrm{mg} / \mathrm{L}$.

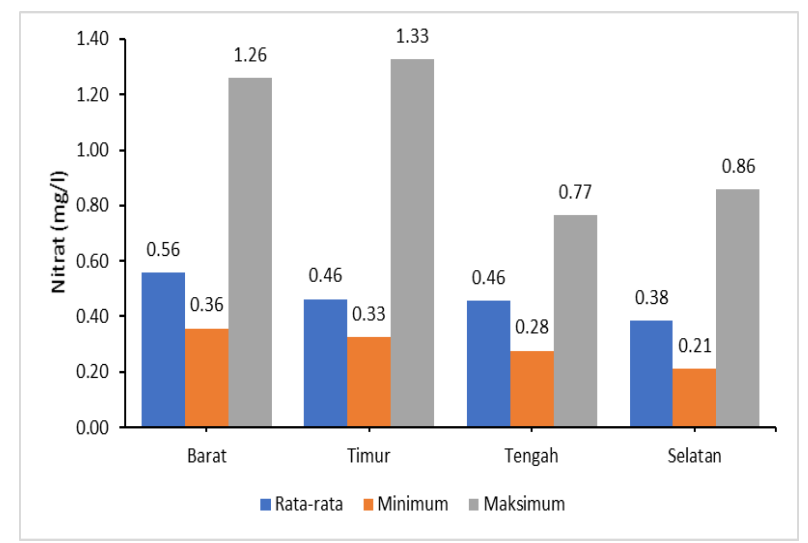

Gambar 13. Grafik Nitrat Kondisi Surut Terendah

Konsentrasi nitrat pada saat kondisi MSL menuju pasang di Perairan Teluk Benoa dapat dilihat pada Gambar 14. Daerah Barat teluk Benoa memiliki konsentrasi nitrat rata-rata 0,56 $\mathrm{mg} / \mathrm{L}$, minimum 0,36 mg/L, dan maksimum 1,34 mg/L. Daerah Timur Teluk Benoa memiliki konsentrasi nitrat rata-rata 0.46 $\mathrm{mg} / \mathrm{L}$, minimum 0,30 mg/L, dan maksimum 1,39 mg/L. Daerah tengah Teluk Benoa memiliki konsentrasi nitrat rata-rata 0,45 $\mathrm{mg} / \mathrm{L}$, minimum $0,22 \mathrm{mg} / \mathrm{L}$, dan maksimum $0,77 \mathrm{mg} / \mathrm{L}$. Sementara pada daerah Selatan Teluk Benoa memiliki 
konsentrasi nitrat rata-rata $0,39 \mathrm{mg} / \mathrm{L}$, minimum $0,21 \mathrm{mg} / \mathrm{L}$ dan maksimum $0,86 \mathrm{mg} / \mathrm{L}$.

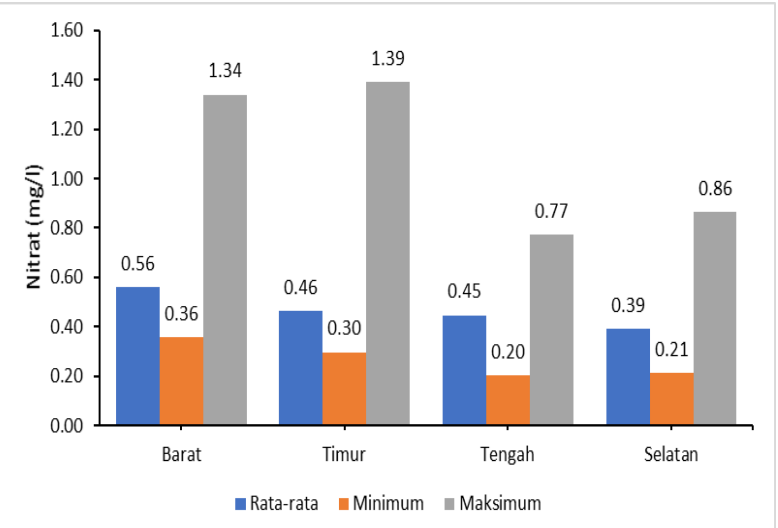

Gambar 14. Grafik Nitrat Kondisi MSL Menuju Pasang

Secara umum konsentasi nitrat yang rendah pada daerah tengah Teluk Benoa dikarenakan daerah tersebut merupakan daerah yang langsung terpengaruh karena pergerakan massa air laut yang besar saat kondisi MSL menuju pasang hingga pasang tertinggi. Daerah Selatan memiliki konsentrasi nitrat yang rendah karena pada daerah tersebut merupakan daerah yang hanya dialiri oleh satu sungai sehingga hanya terdapat satu daerah sebagai tempat untuk masuknya limbah nitrat. Selain itu pada saat pasang tertinggi kondisi pergerakan arus pada daerah tengah Teluk Benoa dominan ke arah Barat, sehingga membatasi pergerekan nitrat yang bersumber dari daerah Barat. Sama halnya ketika kondisi MSL menuju surut hingga surut kondisi pergerakan arus pada daerah tengah Teluk Benoa cenderung ke arah Timur, sehingga kembali membatasi pergerakan nitrat yang bersumber dari daerah Barat. Sementara saat kondisi MSL menuju pasang massa air laut kembali masuk ke Teluk Benoa, sehingga menyebabkan kondisi nitrat pada daerah Selatan kembali rendah.

Sementara konsentrasi nitrat paling besar pada setiap kondsi berada pada daerah Barat dan Timur. Besarnya konsentrasi nitrat pada daerah Barat dan Timur disebabkan oleh beberapa faktor. Pertama, daerah Barat dan Timur sama-sama memiliki dua sungai yang memberi masukan limbah nitrat, dimana untuk daerah Barat bersumber dari Sungai Badung dan Sungai Mati sementara untuk daerah Timur bersumber dari Sungai Loloan dan Sungai Buaji. Kedua, daerah Barat memiliki daerah yang relatif kecil dan dibatasi oleh keberadaan Pelabuhan Benoa serta keberadaan bendungan Sungai Badung, sementara pada daerah Timur memiliki daerah yang relatif sempit (diapit oleh daratan, Pelabuhan Benoa dan, Pulau Serangan) dan memanjang. Ketiga, daerah Teluk Benoa merupakan daerah yang memiliki pertukaran massa air yang rendah dan hampir memerlukan waktu satu bulan untuk memerlukan pertukaran massa air (Hendrawan and Asai, 2014). Dengan adanya faktor-faktor tersebut membuat konsentrasi nitrat pada daerah Barat dan Timur Teluk Benoa cenderung terperangkap dan memiliki konsentrasi nitrat yang tinggi. Hal tersebut senada dengan penelitian sebelumnya yang dilakukan Rahayu et al. (2018) yang menyatakan dengan kondisi perairan Teluk Benoa yang memiliki pertukaran massa air yang rendah dan keberadaan sungai yang terus menerus mengeluarkan limbah menyebabkan konsentrasi nitrat di Teluk Benoa cenderung terakumulasi.

Dari hasil model distribusi nitrat yang didapat, konsentrasi nitrat pada lima sungai yang bermuara di Teluk Benoa dan konsentrasi nitrat pada perairan Teluk Benoa di atas baku mutu yang ditetapkan pada KepMen LH No.51 Tahun 2004 terkait baku mutu air laut untuk biota dan PerGub Bali No.16 Tahun 2016 tentang Baku Mutu Lingkungan Hidup dan Kriteria Baku Kerusakan Lingkungan Hidup yaitu sebesar 0,008 mg/l. Menurut Suteja and Purwiyanto (2018) keadaan konsentrasi nitrat yang melebihi baku mutu pada aliran sungai di Teluk Benoa dapat memicu terjadinya proses eutrofikasi di perairan Teluk Benoa.

\section{b. Pola Distribusi Nitrat di Kolom Perairan}

Kondisi nitrat pada kolom perairan secara vertikal di daerah tengah Teluk Benoa dapat dilihat pada Gambar 15. Analisis cross section dilakukan pada daerah tengah Teluk Benoa dengan menggelar transek sepanjang $4 \mathrm{Km}$ dan lebar transek $0.35 \mathrm{~km}$.

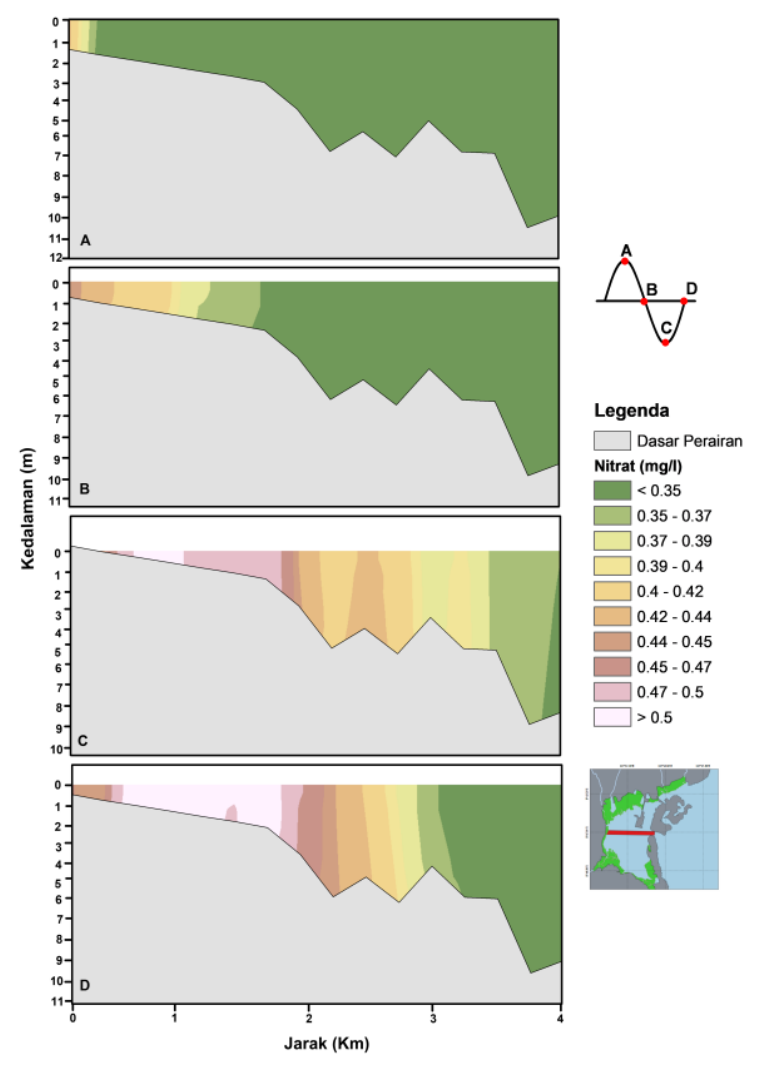

Gambar 15. Pola Distribusi Nitrat di Kolom Perairan Teluk Benoa

Konsentrasi nitrat pada kondisi pasang tertinggi memiliki konsentrasi yang tinggi pada daerah dekat titik nol dengan kisaran dari 0,4 hingga kurang dari $0,35 \mathrm{mg} / \mathrm{L}$ ke arah laut. Hal tersebut dikarenakan massa air laut yang besar bergerak dari arah laut menuju Teluk Benoa. Pada kondisi MSL menuju surut kondisi nitrat semakin besar dan semakin menyebar dari titik nol dengan kisaran dari 0,45 hingga kurang dari $0,35 \mathrm{mg} / \mathrm{L}$ ke arah laut. Penyebaran konsentrasi nitrat tersebut disebabkan karena pergerakan aliran sungai pada saat kondisi MSL menuju surut membuat pergerakan konsentrasi nitrat bergerak jauh menuju arah laut serta pergerakan massa air bergerak dominan ke arah laut. Pada saat surut terendah pergerakan nitrat dominan dipengaruhi oleh aliran sungai yang berasal dari daerah Barat teluk dan Selatan teluk, sehingga konsentrasi nitrat dapat menyebar jauh hingga menacapai 3,5 m dari darat. Konsenrasi nitrat berkisar dari $0,47 \mathrm{mg} / \mathrm{L}$ kemudian meningkat hingga lebih besar dari $0,5 \mathrm{mg} / \mathrm{L}$ karena adanya pengaruh dari aliran sungai yang menuju ke arah laut dan semakin kearah laut konsentrasi nitrat menurun hingga konsentrasi kurang dari $0,35 \mathrm{mg} / \mathrm{L}$. Sementara pada kondisi MSL menuju pasang konsentrasi nitrat cenderung sama seperti kondisi surut terendah, hal tersebut 
dikarenakan pertukaran massa air yang relatif rendah pada daerah Teluk Benoa dan kondisi pergerakan massa air laut baru akan menuju ke arah teluk.

Konsentrasi nitrat di Teluk benoa di pengaruhi oleh elevasi pasang surut. Kondisi nitrat paling tinggi berada pada kondisi surut terendah dan paling rendah berada pada kondisi pasang tertinggi. Konsentrasi nitrat secara vertikal memiliki konsentrasi yang relatif sama. Hal tersebut senada dengan Mubarak and Sulaiman (2016) dimana konsentrasi polutan pada model adveksi-difusi cenderung dipengaruhi oleh elevasi pasang surut dan menurut Zheng et al., (2004) konsentrasi nitrat pada daerah estuari yang memiliki kondisi mixing zone secara vertikal cenderung memiliki konsentrasi nitrat yang relatif sama dari permukaan hingga dasar perairan.

Secara umum dari hasil model distribusi nitrat, konsentrasi nitrat di kolom perairan pada daerah tengah Teluk Benoa telah melewati baku mutu KepMen LH No.51 Tahun 2004 terkait baku mutu air laut untuk biota dan PerGub Bali No.16 Tahun 2016 tentang Baku Mutu Lingkungan Hidup dan Kriteria Baku Kerusakan Lingkungan Hidup yaitu sebesar 0,008 mg/l.

\section{Simpulan}

Konsentrasi nitrat pada bagian permukaan perairan Teluk Benoa cenderung tinggi pada daerah bagian Barat Teluk Benoa dan Timur Teluk Benoa, karena masing-masing daerah memiliki dua aliran sungai, daerah yang relatif kecil dan dibatasi oleh Pelabuhan Benoa dan Bendungan Sungai Badung (daerah Teluk Benoa) dan daerah sempit dan memanjang, serta Teluk Benoa memiliki pertukaraan massa air yang rendah.

Sementara pada bagian kolom perairan di daerah tengah Teluk Benoa, konsentrasi nitrat cenderung dipengaruhi oleh keadaan elevasi pasang surut, konsentrasi nitrat secara vertikal relatif sama dari permukaan hingga dasar perairan, dan konsentasi nitrat semakin besar ke arah darat namun akan semakin menurun ke arah laut.

\section{Ucapan terimakasih}

Dalam pelaksanaan penelitian ini penulis banyak mendapatkan bantuan baik dari perorangan ataupun instansi/lembaga. Oleh karena itu, pada kesempatan ini penulis ingin menyampaikan ucapan terimakasih yang sebesar-besarnya kepada kepala dan staf Laboratorium Komputasi Fakultas Kelautan dan Perikanan atas bantuannya dalam penelitian ini.

\section{Daftar Pustaka}

Al Tanto, T., Wisha, U.J., Kusumah, G., Pranowo, W.S., Husrin, S., Ilham, I. and Putra, A., 2017. Karakteristik Arus Laut Perairan Teluk Benoa-Bali. GEOMATIKA, 23(1), pp.37-48.

Chen, C., Beardsley, R.C. and Cowles, G., 2006. An unstructured grid, finitevolume coastal ocean model-FVCOM user manual, 2nd edn. School for Marine Science and Technology, University of Massachusetts Dartmouth (p. 318). New Bedford. Technical report SMAST/UMASSD-06-0602.

Hendrawan, I.G. and komang Ardana, I., 2010. Numerical calculation of phosphate transport in Benoa Bay, Bali. International Journal of Remote Sensing and Earth Sciences (IJR eSES), 6(1).

Hendrawan, I.G. and Asai, K., 2014. Numerical study on tidal currents and seawater exchange in the Benoa Bay, Bali, Indonesia. Acta Oceanologica Sinica, 33(3), pp.90-100.

Hendrawan, I.G., Uniluha, D. and Maharta, I.P.R.F., 2016. Karakteristik Total Padatan Tersuspensi (Total Suspended Solid) Dan
Kekeruhan (Turbidity) Secara Vertikal Di Perairan Teluk Benoa, Bali. Journal of Marine and Aquatic Sciences, 2(1), pp.29-33.

Kementrian Lingkungan Hidup dan Kehutanan, 2015. Inventarisasi Sumber Pencemar Lingkungan Pesisir dan Laut yang Berasal Dari NonPoint Sources Di Tanjung Benoa.

Lembaga Ilmu Pengetahuan Indonesia, 2015. Eutrofikasi Penyebab Kematian Massal Ikan, (http://lipi.go.id/lipimedia/-eutrofikasipenyebab-kematian-massal-ikan/10464), [diakses: 19 Oktober 2017]

Lembaga Ilmu Pengetahuan Indonesia, 2017. Penelitian Oseanografi di Teluk Jakarta 1970-2015. Jakarta

Maharta IPRF, Hendrawan I G, Suteja Y., 2018. Prediksi Laju Sedimentasi di Perairan Teluk Benoa Menggunakan Pemodelan Numerik. Skripsi. Bukit, Jimbaran: Fakultas Kelautan dan Perikanan, Universitas Udayana.

Maharta, I.P.R.F., Hendrawan, I.G. and Suteja, Y., 2019. Prediksi Laju Sedimentasi di Perairan Teluk Benoa Menggunakan Pemodelan Numerik. Journal of Marine and Aquatic Sciences, 5(1), pp.44-54.

Matsumoto, K., Ooe, M., Sato, T. and Segawa, J., 1995. Ocean tide model obtained from TOPEX/POSEIDON altimetry data. Journal of Geophysical Research: Oceans, 100(C12), pp.25319-25330.

Mubarak, M. and Sulaiman, A., 2016. Analytical model of heavyparticle pollutant transport in estuary. International Journal of Physical Sciences, 11(3), pp.40-49.

Patty, S.I., Arfah, H. and Abdul, M.S., 2015. Zat Hara (Fosfat, Nitrat), Oksigen Terlarut dan $\mathrm{pH}$ Kaitannya dengan Kesuburan di Perairan Jikumerasa, Pulau Buru. Jurnal Pesisir dan Laut Tropis, 1(1), pp.4350.

Rachman, H.A., Hendrawan, I.G. and Putra, I.D.N.N., 2016. Studi Transpor Sedimen di Teluk Benoa Menggunakan Pemodelan Numerik. Jurnal Kelautan: Indonesian Journal of Marine Science and Technology, 9(2), pp.144-154.

Rahayu, N. W. S. T., Hendrawan, I. G., \& Suteja, Y. (2018). Distribusi Nitrat dan Fosfat Secara Spasial dan Temporal Saat Musim Barat Di Permukaan Perairan Teluk Benoa, Bali. Journal of Marine and Aquatic Sciences, 4(1), 1-13.

Risamasu, F.J. and Prayitno, H.B., 2012. Kajian Zat Hara Fosfat, Nitrit, Nitrat dan Silikat di Perairan Kepulauan Matasiri, Kalimantan Selatan. ILMU KELAUTAN: Indonesian Journal of Marine Sciences, 16(3), pp.135-142.

Risuana, I.G.S., Hendrawan, I.G. and Suteja, Y., 2017. Distribusi Spasial Total Padatan Tersuspensi Puncak Musim Hujan Di Permukaan Perairan Teluk Benoa, Bali. Journal of Marine and Aquatic Sciences, 3(2), pp.223-232.

Simanjuntak, M., 2012. Kualitas air laut ditinjau dari aspek zat hara, oksigen terlarut dan $\mathrm{pH}$ di perairan Banggai, Sulawesi Tengah. Jurnal Ilmu dan Teknologi Kelautan Tropis, 4(2), pp.290-303.

Soliwoda, J., 2014. Methods of Vessel Casualty Process Assessment. TransNav: International Journal on Marine Navigation and Safety of Sea Transportation, 8 .

Sugiono, 2012. Metode Penelitian Kuantitatif Kualitatif dan R\&D. Bandung: Alfabeta.

Suteja, Y., 2016. Beban Pencemar Dan Kapasitas Asimilasi Amonium dan Nitrat Saat Pucak Musim Barat di Teluk Jakarta. Journal of Marine and Aquatic Sciences, 2(1), pp.16-22.

Suteja, Y. and Purwiyanto, A.I.S., 2018, June. Nitrate and phosphate from rivers as mitigation of eutrophication in Benoa bay, BaliIndonesia. In IOP Conference Series: Earth and Environmental Science (Vol. 162, No. 1, p. 012021). IOP Publishing.

Tuahattu, W.J. and Tubalanowy, S., 2008. Sebaran Nitrat dan Fosfat Pada Massa Air Permukaan Selama Bulan Mei 2008 Di Teluk Ambon Bagian Dalam. Triton (Jurnal Manajemen Sumberdaya Perairan)(5), pp.34-40.

Zheng, L., Chen, C. and Zhang, F.Y., 2004. Development of water quality model in the Satilla River Estuary, Georgia. Ecological modelling, 178(3-4), pp.457-482. 